\title{
How People Foraging in Urban Greenspace Can Mobilize Social-Ecological Resilience During Covid-19 and Beyond
}

\author{
Mallika Sardeshpande ${ }^{1,2 \star}$, Patrick T. Hurley ${ }^{3}$, Eefke Mollee ${ }^{4}$, Hesekia Garekae ${ }^{5}$, \\ Annika C. Dahlberg ${ }^{6}$, Marla R. Emery ${ }^{7}$ and Charlie Shackleton ${ }^{5}$ \\ ${ }^{1}$ Centre for Transformative Agriculture and Food Systems, School of Agriculture, Engineering, and Environmental Science, \\ University of KwaZulu-Natal, Durban, South Africa, ${ }^{2}$ Ashoka Trust for Research in Ecology and the Environment, Bangalore, \\ India, ${ }^{3}$ Department of Environmental Studies, Ursinus College, Collegeville, PA, United States, ${ }^{4}$ School of Natural Sciences, \\ Bangor University, Bangor, United Kingdom, ${ }^{5}$ Department of Environmental Science, Rhodes University, Makhanda, South \\ Africa, ${ }^{6}$ Department of Physical Geography, Stockholm University, Stockholm, Sweden, ${ }^{7}$ Forest Service, US Department of \\ Agriculture, Burlington, VT, United States
}

OPEN ACCESS

Edited by:

Erika S. Svendsen,

Northern Research Station,

United States Forest Service (USDA),

United States

Reviewed by:

Paunita Iuliana Boanca,

University of Agricultural Sciences and Veterinary Medicine of

Cluj-Napoca, Romania

Christie Manning,

Macalester College, United States

${ }^{*}$ Correspondence:

Mallika Sardeshpande

sardeshpandem@ukzn.ac.za

Specialty section:

This article was submitted to Urban Resource Management, a section of the journal

Frontiers in Sustainable Cities

Received: 26 March 2021 Accepted: 19 November 2021 Published: 23 December 2021

Citation:

Sardeshpande M, Hurley PT, Mollee E, Garekae H, Dahlberg AC, Emery MR and Shackleton C (2021) How People

Foraging in Urban Greenspace Can Mobilize Social-Ecological Resilience

During Covid-19 and Beyond.

Front. Sustain. Cities 3:686254. doi: 10.3389/frsc.2021.686254
Informal foraging for food and other natural materials in urban greenspaces is an activity undertaken by many across the world. For some, foraging is a necessary means of survival and livelihood, while for others, it provides cultural and recreational opportunities. In the socioeconomic crises induced by Covid-19, foraging can help communities, especially (but not exclusively) vulnerable people, cope with the impacts of lockdowns, and associated economic decline. In the long run, foraging can help improve socialecological resilience in urban systems, particularly in response to climate, economic, and disease disruptions. First, we elaborate the ways in which urban foraging can provide immediate relief from the shocks to natural, human, social, physical, and financial capital. We then describe how over time, the livelihood, food, and income diversification brought about by foraging can contribute to preparedness for future uncertainties and gradual change. Cities are increasingly becoming home to the majority of humanity, and urban foraging can be one of the pathways that makes cities more liveable, for humans as well as other species we coexist with. Through the capitals framework, we explore the role foraging could play in addressing issues of biodiversity conservation, culture, and education, good governance and social justice, multifunctional greenspace, and sustainable nature-based livelihoods in urban areas.

Keywords: capital, climate change, pandemic, resilience, urban foraging, urban greenspace, urban green infrastructure, adaptation

\section{INTRODUCTION}

Zandile picks various wild berries for her family and for sale in the neighborhood on her way to work and back in Durban (South Africa). Hal, the son of Chinese immigrants, harvests ginkgo nuts from the sidewalk during walks in a nearby park in his New York (USA) neighborhood, incorporating these in traditional Chinese dishes served at community celebrations. These urbanites are engaged in urban foraging, the practice of collecting naturally growing materials such as fruits, fungi, herbs, craft materials, and wood from urban greenspaces (Shackleton et al., 2017b). 
Examples of urban greenspaces include public gardens and parks, riversides, sidewalks, and vacant lots. During pre-covid times, many people across the world foraged in urban areas for various reasons. For example, in some households, foraging helps supplement food supply or save expenses on food or firewood (Shackleton et al., 2017a). In some places, foragers collect craft materials and medicinal herbs for their own household needs, for recreation, or for sale (Poe et al., 2013). For others, foraging is part of cultural practices such as preparing traditional food cuisines using ingredients sourced from the urban wild and lighting firewood at night as a way of connecting with ancestors (Garekae and Shackleton, 2020). Some foragers may sell the materials they gather, in raw form (e.g., fruits, blossoms, and grass blades) or as processed products (e.g., jams, tinctures, baskets, brooms, and mats), to earn an income (Landor-Yamagata et al., 2018). Foraging holds multiple values in people's lives, supporting cultural, economic, and recreational needs.

Covid-19 lockdowns have had various cascading impacts on almost all walks of life. The loss of 195 million jobs, combined with an impending recession, has increased global poverty drastically (IMF., 2020). Disruptions in food supply chains have resulted in food shortages in many countries, making the poor and unemployed even more vulnerable to malnutrition (Torero, 2020). The focus on the pandemic response has deprived other patients of healthcare in some cases. Lockdown restrictions and drastic changes in socioeconomic conditions have also affected people's mental health (Pierce et al., 2020). With Covid-19, many nations across the world imposed varying degrees of lockdowns, affecting urban foraging behavior differently; in some cities, access to greenspaces and hence foraging has been restricted, while in other cities, people are spending more time in urban greenspaces (Kleinschroth and Kowarik, 2020; Ugolini et al., 2020; Venter et al., 2020). The impacts of the pandemic and related restrictions on foraging are yet to emerge, but foraging has been well-documented as a coping strategy during times of natural, economic, and political crises (Erskine et al., 2015; Hofman, 2016; Weyer et al., 2018). In this article, we first elaborate how foraging can help urban communities cope with the short-term impacts of the Covid-19 pandemic. Then, we consider the longer-term implications of adapting urban systems to better respond to future disruptions, including climate change. We use the five capitals framework (natural, human, social, physical, and financial) to assess the changes brought about by Covid-19 and foreseeable climate change impacts and the ways in which urban foraging can ameliorate them.

\section{FIVE CAPITALS FRAMEWORK}

The five capitals framework provides an assessment of the status of a social-ecological system, based on its components. These components are natural (the ecological context), human (individual and household capacity), social (community and institutional networks), physical (built infrastructure), and financial (the economic context) capitals. The five capitals form a subset of the sustainable livelihoods framework (Serrat, 2017), which additionally also includes the contexts of vulnerability, policy, processes, and institutions, and sustainable livelihoods outcomes. We choose to use the five capitals framework because foraging is generally not considered a livelihood, but a part of a suite of livelihood activities (Reyes-García et al., 2018), and has little interaction with policies or institutions. We document and speculate on short-term and long-term changes in these five capitals and how forging may be influenced by or induce adaptation in the face of these changes. The five capitals framework can be used to plan sustainable development by setting specific targets and comparing capital combinations under various scenarios (Davenport et al., 2019). It can also be used to analyze the capacity of an existing system to adapt to gradual changes driven by deliberate motivation or exogenous factors (Cafer et al., 2019). Furthermore, in the event of unforeseen disasters, the framework also helps to measure risk and resilience and plan relief and rehabilitation (Laurien et al., 2020). We use the five capitals framework to conceptually assess the impacts of the systemic shocks delivered by the Covid-19 pandemic lockdowns on urban systems. We then extend this assessment to foreseeable gradual transitions driven by climate change. In each case, we elaborate the benefits foraging can offer to ameliorate the short- and long-term impacts on the five capitals (Figure 1).

\section{SHORT-TERM RELIEF}

In addition to the impacts listed above, Covid-19 has had far-reaching effects on almost every aspect of life. Stay-at-home measures and restricted movement have redistributed demand and pressures across various industries. For example, the use of transport and office infrastructure has reduced, with a steep increase in the demand for energy and electronics at home (Parker, 2020). As industrial fuel and energy consumption reduced, domestic electricity demands rose, and carbon emissions dipped beneath their usual levels temporarily (Aruga et al., 2020; Dantas et al., 2020; Wang and Su, 2020). In some cases, the workforce from large factories has had to forgo a period of earnings and depend on local food charities and gardens instead (Clay and Rogus, 2021). Communal structures of work, education, and care have been disrupted, reducing the benefits to households that depend on these services (Blundell et al., 2020). Distancing measures have also put a strain on the social fabric and reduced opportunities for collective interaction and recreation (Majumdar et al., 2020). Thus, natural capital in urban areas has experienced a fluctuation and reconfiguration of anthropogenic demands and, particularly, an increase in small-scale provisioning and cultural services in the form of household and individual use of greenspaces for food and recreation. Similarly, physical infrastructure has experienced a shift from packed offices and public transport to staggered and spaced use of public facilities including roads and parks (Barbieri et al., 2021). In some cases, this has allowed for wilderness to "reclaim" some urban landscapes, which is perceived positively by many city dwellers. The onus of managing human capital has, to an extent, been devolved to the household (Power, 2020), with reduced capacities of schools, child, and elderly 


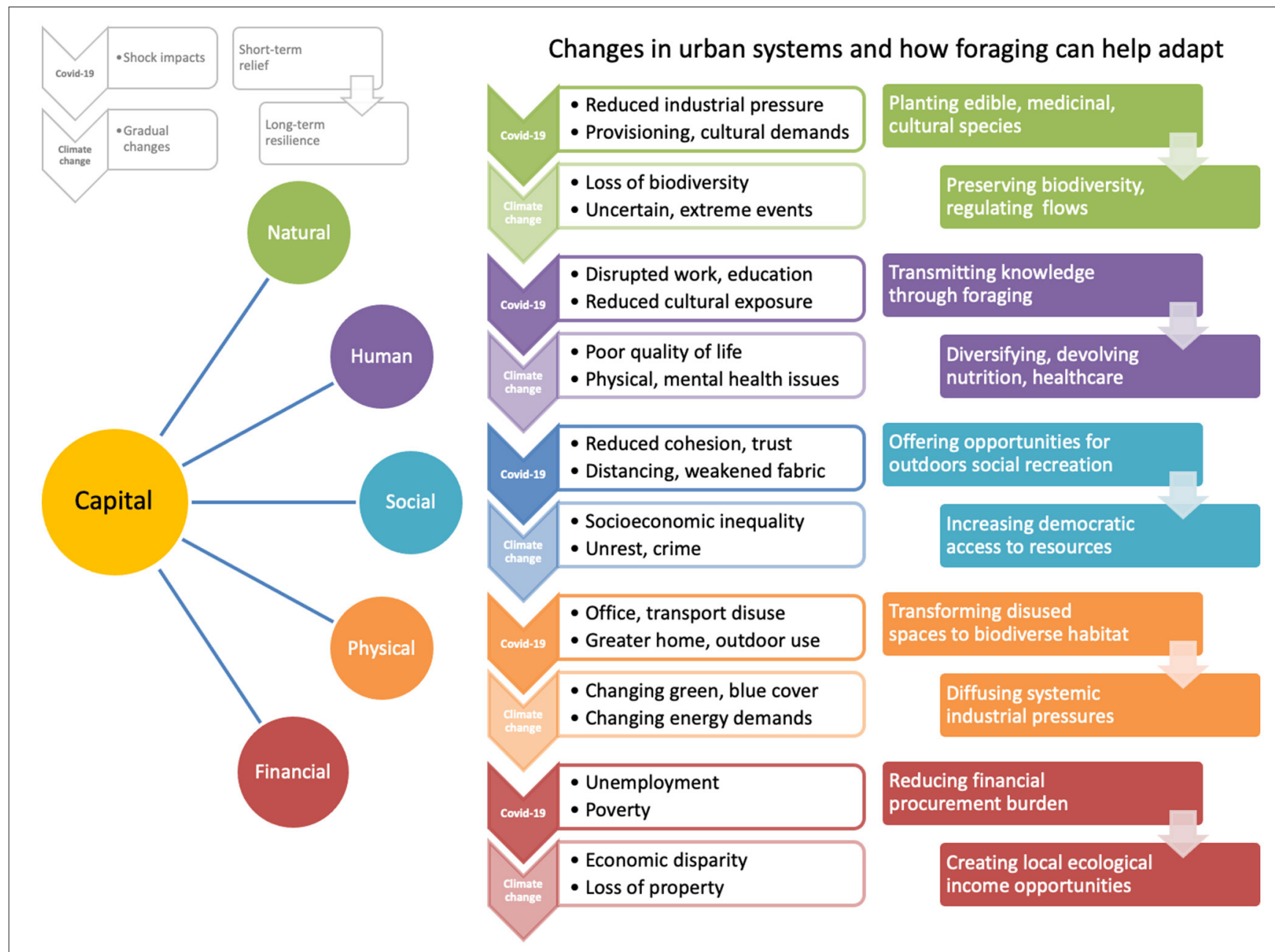

FIGURE 1 | How urban foraging can help adapt to shock impacts and gradual changes in the five capitals in urban social-ecological systems.

care, and offices to accommodate their usual volumes. Social capital is similarly weakened by the outlawing of gatherings or physically close interactions between people (Arthi and Parman, 2021). Financial capital is decimated not only by job losses but also by reduced spending due to pay cuts, business losses, and dwindling savings (Piyapromdee and Spittal, 2020; Walmsley et al., 2020).

Foraging in urban greenspaces provides people with alternatives in more ways than one. For one, it increases food accessibility: allowing people to procure food and other resources for free, saving costs for those in need, and providing options to others. For example, commercial produce may be too expensive or government food aid too meager for some households. While some urban residents turn to growing food in their home gardens (Sofo and Sofo, 2020), this may not be possible for apartment dwellers or migrant workers. Foraging is a source of fresh and local food, crucial at a time when global food supply is constricted (Laborde et al., 2020). Foraged food is a source of micronutrients from foods such as wild fruits and vegetables (Ejoh et al., 2019; Ray et al., 2020) and proteins from foods like wild seaweed and insects (Manditsera et al., 2019; Skrzypczyk et al., 2019). These micronutrients and proteins may be unavailable or unaffordable to many (Headey et al., 2020) yet may be important in building the immune response to various diseases (Jayawardena et al., 2020). In addition to sustenance and nutrition, foraging can also improve prospects for physical and mental health for city dwellers. Some foragers collect medicinal herbs and are holders of knowledge of traditional therapies and cures for various ailments (Mollee et al., 2017). This decentralized form of medicine can aid those unable to access mainstream healthcare systems for various reasons. This is especially important in the time of this pandemic, where Covid-19 cases are being prioritized over other patients with curable or chronic illnesses (Chudasama et al., 2020), and people are finding themselves without income or medical cover to pay for health-related expenses (Ahmed et al., 2020). Furthermore, the practice of foraging has therapeutic and enriching benefits similar to other recreational activities 
in greenspaces (Engemann et al., 2019). Thus, foraging could contribute to the health and well-being response to the current crises in the short- and long-term, by supporting human and social capital.

Beyond food and health alternatives, foraging can help people save expenditures on a number of household materials (Kazungu et al., 2020). Among the most prominent of these is electricity or fuel for cooking and heating, which can be replaced with foraged firewood or other foraged plant fuels (Maroyi, 2014). Another important aspect of foraging is the ability to generate income. Those with knowledge of useful species and processing techniques can sell their products, such as tinctures, baskets, and mats, to earn money that might be critical to surviving the loss of other sources of income (Weyer et al., 2018). Thus, by providing opportunities to save and earn money, foraging can allow urban residents of all socioeconomic backgrounds to attain a level of self-sufficiency and sovereignty over their household economy, by building financial capital. Foraging in public spaces can act as an educational activity, allowing for transfer of knowledge about food production, ecosystem flows, and urban governance (Colinas et al., 2019). We suggest that the current situation presents several opportunities for urban foraging to bolster socioeconomic recovery. In addition to answering to increased demands on natural and financial capital, urban foraging can diversify means of maintaining and augmenting human and social capital. For example, foraging affords people the opportunity to attain personal spiritual satisfaction (Chou, 2018; Nyman, 2019) and promotes intergenerational interaction and knowledge transfer (Hake, 2017; Fischer and Kowarik, 2020). The changes in the use of physical infrastructure also offer new avenues for integrating provisioning features through planting for and legitimizing foraging in public spaces (e.g., Pinheiro and Luís, 2020; Sardeshpande et al., 2020). Once in place, these decentralized and diversified systems of generating capital can help insure cities against a range of shocks and gradual changes in the future (Lai et al., 2020). Advances in natural and physical capital are likely to be observed under more long-term scenarios.

\section{LONG-TERM RESILIENCE}

Cities are at the forefront of human development, with landscapes in constant flux and dynamic demographic and socioeconomic structures (Iveson et al., 2019; Morrow and Martin, 2019). Disruptions and changes of any nature tend to be amplified in cities, due to their institutional, financial, and physical capacity (Petrescu et al., 2020). Climate change is severely impacting natural systems, with cascading effects on human and social capital and damage to physical and financial assets. Rising temperatures and sea levels, along with unpredictable and extreme weather events, are contributing to the global loss of biodiversity and habitats (Pecl et al., 2017). This loss is exacerbated by related disaster events such as droughts, floods, and fires, which also render more habitat unsuitable for humans and wildlife (Anderson et al., 2018). The loss of biodiversity (animals, plants, and lots more) disrupts the flow of greenhouse gases, soil nutrients, and water (among other things) in ecosystems, making them less efficient at regulating weather, growing crops, holding fresh water, and so on (Ullah et al., 2018). This reduction in habitable land, potable water, and access to food will have grave consequences for human society and quality of life, particularly for the poor (Robinson and Shine, 2018). Furthermore, frequent and unforeseen natural disasters may threaten infrastructure and financial resources. The causes and effects of climate change are diffused across time and space and interconnected in a myriad of ways. Much of the contribution to climate change comes from industrial production and processing of resources and their distribution across the globe (Sarkodie et al., 2020). Industrial production converts large tracts of land spanning diverse ecosystems for a single use, often with intensive inputs that are sourced from other industrial ecosystems (Dumaresq and Pittock, 2018). For example, industrial agriculture uses fertilizers, fuel, and water transported across large distances to grow a single species of crop (Rockström et al., 2020). Similarly, cities are designed to deliver secondary production of goods and services in factories and offices, with low priority given to provision of accessible and interactive natural spaces. Localizing and diversifying resource production can reduce the impact of industries (e.g., Downs et al., 2020; Piñeiro et al., 2020), including through foraging. De-densifying and interspersing industrial spaces with multifunctional natural spaces (e.g., Leclère et al., 2020) will help conserve urban biodiversity while also providing ecosystem services for human well-being.

Some plant species that are foraged by humans are also attractive to other animal consumers and pollinators like birds, insects, and mammals, allowing them to safely inhabit urban greenspaces or pass through them to other wilderness areas (Champness et al., 2019; Zietsman et al., 2019). Therefore, planting and maintaining spaces and species for foraging is likely to allow for greater coexistence and diversity of plant and animal species alongside humans in cities (Bonthoux et al., 2014; Botzat et al., 2016), therefore enhancing natural capital. By utilizing foraged species that are not part of mainstream economies, foragers preserve and propagate important knowledge. Many lesser known and underutilized species are packed with more micronutrients than staple crops, and some are resistant to harsh weather conditions (Mabhaudhi et al., 2017). These species may be very useful as the deepening effects of climate change challenge conventional agriculture and call for more locally adapted and efficient crops (Hadebe et al., 2021). In some cases, these nutrient-rich and hardy species are already widely available in urban environments (Phillips et al., 2014). Incorporating natural and local diversity into production systems helps regulate ecosystem flows and buffer against disasters (Kremen and Merenlender, 2018), forming resilient ecological infrastructure, which can be considered physical capital. Because moderation in industrial landscapes reduces environmental damage, it also reduces the risk of health hazards from pollution and zoonoses precipitated or exacerbated by industrial use (Ahmed et al., 2019; Rohr et al., 2019). Thus, foraging is part of a suite of strategies to diffuse pressure on conventional and industrial systems while simultaneously strengthening the self-sufficiency and functionality of natural and physical capital in urban areas. 
Foraging can offer people additional control over and options for their food, health, income, and expenditure. In doing so, it also requires people to govern their resources more locally and sustainably. For example, citizens in Copenhagen have developed an app to promote information about sustainable foraging in greenspaces within the city (Buijs et al., 2019). Furthermore, people who forage often also tend to the spaces they forage in, by managing waste, removing invasive alien species, and educating interested people about such practices (Hake, 2017; McLain et al., 2017), thereby maintaining their ecological infrastructure and physical capital. In this way, foraging can mobilize good governance specific to the local context in the interest of the common good. Such governance mechanisms can then also be extended to collaborations with municipalities for better urban planning and management of urban biodiversity (Colinas et al., 2019; Sardeshpande and Shackleton, 2020). In particular, improving the provision of and access to greenspaces across the socioeconomic spectrum could help ensure that the benefits related to foraging are distributed equitably (Kabisch and Haase, 2014; Wolch et al., 2014), improving the distribution of physical capital and the development of social capital. Foraging does and will continue to play an important role in democratizing access to and co-production of ecosystem goods and services in cities. Furthermore, foraging also allows people to derive nature-based livelihoods in cities, building financial capacity, and diversity. The culture and knowledge of indigenous food, medicine, and materials form an integral part of the relationship between nature and humans (Elands et al., 2019). This relationship may also emerge through engagements with cosmopolitan species and novel plant communities in cities (Hurley et al., 2015; Fischer and Kowarik, 2020), and foraging is a potent expression of this relationship. Thus, foraging is a potentially important contributor to social, physical, and financial capital through improved quality of life, devolved governance, and sustainable livelihoods.

Urban greenspace, and the material resources contained therein, is unevenly distributed within cities, raising concerns about access and other issues of environmental justice with foraging (Poe et al., 2013; Hurley et al., 2015; Rigolon, 2016; Hurley and Emery, 2018). Following Schlosberg (2007), access is defined here along several dimensions, including distribution: having a greenspace such as a park near to you; recognition: that all stakeholders must be recognized for the values they seek in a greenspace; procedural justice: that stakeholders are involved in decision-making at different stages in urban planning; and capabilities: that people have individual capabilities to transform their situation. Capabilities differ enormously among individuals, and several scholars highlight the risk of seeing communities as homogenous in planning and decision-making processes (Walker and Hurley, 2004; Svarstad and Benjaminsen, 2020). These scholars further point out the importance in recognizing how power issues shape planning processes and may challenge environmental justice assumptions. In an urban context, research must widen from a focus on greenspace function and management to study what residents want in decision making (Rutt and Gulsrud,
2016), including incorporation of the values and needs of urban foragers in these processes (Poe et al., 2013; Hurley et al., 2015).

\section{EMERGING EVIDENCE FROM 2020}

As the world moves on from drastic socioeconomic change into a "new normal," foraging offers an opportunity to contribute to the resilience of urban social-ecological systems and physical infrastructure. An example of an emerging response to shock is the Wild Foodies of Philadelphia, a social group founded in 2010 that "promote[s] public wild edibles" (Wild Foodies of Philadelphia., 2016). With about 5,000 members, the group organizes visits to diverse urban greenspaces; maintains an online library detailing utility of various plant species; and publishes a weekly newsletter featuring common as well as historical uses of native, non-native, and cosmopolitan species found in the city. The arrival of Covid-19 in March 2020 brought forceful but relatively short-lived "stay-at-home" orders to the Philadelphia metropolitan area, which included closure of public parks and some community gardens. While such orders made the typical spring meet-ups of the past illegal, email communications by group members explored how foraging could be incorporated into outdoor exercise (biking, running, and walking), which was still permissible. Newsletters continued to circulate, focusing on new edible species beginning to appear in new places in the landscape, including along sidewalks or roadsides in the countryside, and announcing locations for curbside pick-up of wild gathered foods in the city. By early May, the easing of these limits meant that residents of the city and its suburbs could use public parks, and the group resumed its foraging meet-ups. As summer continued, new locations featured in meet-ups and waitlists to participate in events became a regular occurrence. Through summer and fall, emails about newly emerging plants were featured in the group's online library or newsletters. In winter 2020, for the first time, the group embraced Zoom to organize virtual meet-ups on winter foraging. The event went so well, that the group has launched a new series of monthly digital meet-ups, featuring 10 different useful plant taxa, in which participants are provided with information to study in advance of the digital session. This example highlights the evolution of social capital linked to foraging to adapt to new forms of connection and communication. The communications and documentations of the Wild Foodies of Philadelphia may also provide information on changes in natural and physical capital (e.g., species and spaces related to foraging) and human and financial capital (e.g., participant motivations and foraged product sales).

\section{QUESTIONS FOR THE FUTURE}

The example above indicates that foraging has adapted to changing circumstances, by adopting new ways of fulfilling the need for human social interaction, and that natural and physical environments may indeed have undergone changes that 
favor foraging. In light of these observations, we propose that upcoming studies on foraging investigate if and how

1. Demands on and interest in the local natural environment have increased (natural and physical capital): Has the quantum of extraction increased or decreased in response to restrictions and socioeconomic conditions across different geographies? Is foraging being forgone or undertaken in places previously used, unused, or used differently?

2. Personal motivations for and social connections in foraging have changed (human and social capital): Has the proportion of people foraging for subsistence or recreation changed significantly? Are different demographics engaging in foraging? Has knowledge transmission changed due to pandemic-related restrictions?

3. Foraging has made significant economic and other contributions to people's lives (financial and human capital): Besides intrinsic motivations, has foraging been driven by extrinsic factors such as unemployment, reskilling, mental health, financial difficulties, etc.? Can the contributions of foraging to people's lives be qualified or quantified?

4. Foraging has and can be incorporated into socially just urban design (social and physical capital): Has foraging created, strengthened, or weakened social connections and sense of community over time, particularly during the pandemic? Has foraging brought to light gaps or bridges in planning and production of physical infrastructure?

While urban foraging is not a panacea, it offers one widely accessible strategy with low barriers to entry for short-term relief, mid-term recovery from the crises, and long-term resilience in the face of both disruptive changes such as the pandemic and more gradual ones such as climate change.

\section{REFERENCES}

Ahmed, S., Dávila, J. D., Allen, A., Haklay, M., Tacoli, C., and Fèvre, E. M. (2019). Does urbanization make emergence of zoonosis more likely? Evidence, myths and gaps. Environ. Urban. 31, 443-460. doi: 10.1177/0956247819866124

Ahmed, S. A. S., Ajisola, M., Azeem, K., Bakibinga, P., Chen, Y. F., Choudhury, N. N., et al. (2020). Impact of the societal response to COVID-19 on access to healthcare for non-COVID-19 health issues in slum communities of Bangladesh, Kenya, Nigeria and Pakistan: results of pre-COVID and COVID-19 lockdown stakeholder engagements. BMJ Glob. Health 5, e003042. doi: 10.1136/bmjgh-2020-003042

Anderson, S. E., Bart, R. R., Kennedy, M. C., MacDonald, A. J., Moritz, M. A., Plantinga, A. J., et al. (2018). The dangers of disaster-driven responses to climate change. Nat. Clim. Chang. 8, 651-653. doi: 10.1038/s41558-018-0208-8

Arthi, V., and Parman, J. (2021). Disease, downturns, and wellbeing: economic history and the long-run impacts of COVID-19. Explor. Econ. Hist. 79, 101-181.

Aruga, K., Islam, M. M., and Jannat, A. (2020). Effects of COVID-19 on Indian energy consumption. Sustainability 12, 5616. doi: 10.3390/su121 45616

Barbieri, D. M., Lou, B., Passavanti, M., Hui, C., Hoff, I., Lessa, D. A., et al. (2021). Impact of COVID-19 pandemic on mobility in ten countries and associated perceived risk for all transport modes. PLOS ONE 16, e0245886. doi: 10.1371/journal.pone.0245886

Blundell, R., Costa Dias, M., Joyce, R., and Xu, X. (2020). COVID-19 and Inequalities. Fisc. Stud. 41, 291-319. doi: 10.1111/1475-5890.12232

\section{DATA AVAILABILITY STATEMENT}

The original contributions presented in the study are included in the article/supplementary material, further inquiries can be directed to the corresponding authors.

\section{AUTHOR CONTRIBUTIONS}

MS drafted the article with critical and intellectual contributions from all other authors. All authors contributed to the article and approved the submitted version.

\section{FUNDING}

$\mathrm{PH}$ is funded by the Dean's Office, Ursinus College. CS was supported by the South African Research Chairs Initiative of the Department of Science and Innovation and the National Research Foundation of South Africa (grant no. 84379). Any opinion, finding, conclusion, or recommendation expressed in this material is that of the authors, and the NRF does not accept any liability in this regard. The contribution by $\mathrm{AD}$ was supported by the Swedish Research Council Formas. MS was supported by the Wellcome Trust through the Sustainable and Healthy Food Systems (SHEFS) Project (grant no. 205200/Z/16/Z).

\section{ACKNOWLEDGMENTS}

PH acknowledges Kristin McGillis and Dr. Joana Chan for assistance with field work in Philadelphia and New York, respectively, which inform research insights presented here.

Bonthoux, S., Brun, M., Di Pietro, F., Greulich, S., and Bouché-Pillon, S. (2014). How can wastelands promote biodiversity in cities? A review. Landscape Urban Plann. 132, 79-88. doi: 10.1016/j.landurbplan.2014.08.010

Botzat, A., Fischer, L. K., and Kowarik, I. (2016). Unexploited opportunities in understanding liveable and biodiverse cities. A review on urban biodiversity perception and valuation. Glob. Environ. Change 39, 220-233. doi: 10.1016/j.gloenvcha.2016.04.008

Buijs, A., Hansen, R., Van der Jagt, S., Ambrose-Oji, B., Elands, B., Rall, E. L., et al. (2019). Mosaic governance for urban green infrastructure: upscaling active citizenship from a local government perspective. Urb. For. Urb. Green. 40, 53-62. doi: 10.1016/j.ufug.2018.06.011

Cafer, A., Green, J., and Goreham, G. (2019). A Community Resilience Framework for community development practitioners building equity and adaptive capacity. J. Community Dev. 50, 201-216.

Champness, B. S., Palmer, G. C., and Fitzsimons, J. A. (2019). Bringing the city to the country: relationships between streetscape vegetation type and bird assemblages in a major regional centre. J. Urb. Ecol. 5, juz018. doi: 10.1093/jue/juz018

Chou, S. (2018). Chinatown and beyond: ava chin, urban foraging, and a new American cityscape. Interdiscipl. Stud. Liter. Environ. 25, 5-24. doi: 10.1093/isle/isy009

Chudasama, Y. V., Gillies, C. L., Zaccardi, F., Coles, B., Davies, M. J., Seidu, S., et al. (2020). Impact of COVID-19 on routine care for chronic diseases: a global survey of views from healthcare professionals. Diab. Metab. Syndr. Clin. Res. Rev. 14, 965-967. doi: 10.1016/j.dsx.2020.06.042 
Clay, L. A., and Rogus, S. (2021). Impact of employment, essential work, and risk factors on food access during the COVID-19 pandemic in New York state. Int. J. Environ. Res. Publ. Health 18, 1451. doi: 10.3390/ijerph18041451

Colinas, J., Bush, P., and Manaugh, K. (2019). The socio-environmental impacts of public urban fruit trees: a Montreal case-study. Urb. Forest. Urb. Green. 45, 126132. doi: 10.1016/j.ufug.2018.05.002

Dantas, G., Siciliano, B., França, B. B., da Silva, C. M., and Arbilla, G. (2020). The impact of COVID-19 partial lockdown on the air quality of the city of Rio de Janeiro, Brazil. Sci. Total Environ. 729, 139085. doi: 10.1016/j.scitotenv.2020.139085

Davenport, M., Delport, M., Blignaut, J. N., Hichert, T., and Van der Burgh, G. (2019). Combining theory and wisdom in pragmatic, scenario-based decision support for sustainable development. J. Environ. Plan. Manag. 62, 692-716.

Downs, S. M., Ahmed, S., Fanzo, J., and Herforth, A. (2020). Food environment typology: advancing an expanded definition, framework, and methodological approach for improved characterization of wild, cultivated, and built food environments toward sustainable diets. Foods 9, 532. doi: $10.3390 /$ foods 9040532

Dumaresq, D., and Pittock, J. (2018). Impacts of rice intensification on rural households in the Mekong Delta: emerging relationships between agricultural production, wild food supply and food consumption. Food Secur. 10, 1615-1629. doi: 10.1007/s12571-018-0848-6

Ejoh, S. I., Wireko-Manu, F. D., Page, D., and Renard, C. M. (2019). Traditional green leafy vegetables as underutilised sources of micronutrients in a rural farming community in south-west Nigeria I: estimation of vitamin C, carotenoids and mineral contents. South Afr. J. Clin. Nutr. 34, 1-6. doi: 10.1080/16070658.2019.1652963

Elands, B. H. M., Vierikko, K., Andersson, E., Fischer, L. K., Goncalves, P., Haase, D., et al. (2019). Biocultural diversity: a novel concept to assess human-nature interrelations, nature conservation and stewardship in cities. Urb. Forest. Urb. Green. 40, 29-34. doi: 10.1016/j.ufug.2018.04.006

Engemann, K., Pedersen, C. B., Arge, L., Tsirogiannis, C., Mortensen, P. B., and Svenning, J. C. (2019). Residential green space in childhood is associated with lower risk of psychiatric disorders from adolescence into adulthood. Proc. Nat. Acad. Sci. U.S.A. 116, 5188-5193. doi: 10.1073/pnas. 1807504116

Erskine, W., Ximenes, A., Glazebrook, D., da Costa, M., Lopes, M., Spyckerelle, L., et al. (2015). The role of wild foods in food security: the example of Timor-Leste. Food Secur. 7, 55-65. doi: 10.1007/s12571-014-0406-9

Fischer, L. K., and Kowarik, I. (2020). Connecting people to biodiversity in cities of tomorrow: is urban foraging a powerful tool?. Ecol. Indic. 112, 106087. doi: 10.1016/j.ecolind.2020.106087

Garekae, H., and Shackleton, C. M. (2020). Urban foraging of wild plants in two medium-sized South African towns: people, perceptions and practices. Urb. Forest. Urb. Green. 49, 126581. doi: 10.1016/j.ufug.2020.126581

Hadebe, S. T., Modi, A. T., and Mabhaudhi, T. (2021). Assessing suitability of sorghum to alleviate sub-saharan nutritional deficiencies through the nutritional water productivity index in semi-arid regions. Foods. 10:385

Hake, B. J. (2017). Gardens as learning spaces: intergenerational learning in urban food gardens. J. Intergener. Relatsh. 15, 26-38. doi: $10.1080 / 15350770.2017 .1260369$

Headey, D., Heidkamp, R., Osendarp, S., Ruel, M., Scott, N., Black, R., et al. (2020). Impacts of COVID-19 on childhood malnutrition and nutrition-related mortality. Lancet 396, 519-521. doi: 10.1016/S0140-6736(20)31647-0

Hofman, N. G. (2016). Bridging food scarcity: Croatian women's responses to consumer capitalism. Cult. Agric. Food Environ. 38, 48-56. doi: 10.1111/cuag. 12065

Hurley, P. T., and Emery, M. R. (2018). Locating provisioning ecosystem services in urban forests: forageable woody species in New York City, USA. Landsc. Urban Plan. 70, 266-275. doi: 10.1016/j.landurbplan.2017.09.025

Hurley, P. T., Emery, M. R., McLain, R., Poe, M., Grabbatin, B., and Goetcheus, C. L. (2015). "Whose urban forest? The political ecology of foraging urban nontimber forest products," in Sustainability in the Global City: Myth and Practice, eds C. Isenhour, G. McDonagh, and M., Checker (New York, NY: Cambridge University Press), 187-212. doi: 10.1017/CBO9781139923316.014

IMF. (2020). Available online at: https://blogs.imf.org/2020/04/14/the-greatlockdown-worst-economic-downturn-since-the-great-depression/ (accessed March 12, 2021).
Iveson, K., Lyons, C., Clark, S., and Weir, S. (2019). The informal Australian city. Aust. Geogr. 50, 11-27. doi: 10.1080/00049182.2018.1505286

Jayawardena, R., Sooriyaarachchi, P., Chourdakis, M., Jeewandara, C., and Ranasinghe, P. (2020). Enhancing immunity in viral infections, with special emphasis on COVID-19: a review. Diab. Metab. Synd. Clin. Res. Rev. 14, 367-382. doi: 10.1016/j.dsx.2020.04.015

Kabisch, N., and Haase, D. (2014). Green justice or just green? Provision of urban green spaces in Berlin, Germany. Landsc. Urb. Plann. 122, 129-139. doi: 10.1016/j.landurbplan.2013.11.016

Kazungu, M., Zhunusova, E., Yang, A. L., Kabwe, G., Gumbo, D. J., and Günter, S. (2020). Forest use strategies and their determinants among rural households in the miombo woodlands of the copperbelt province, Zambia. For. Policy Econ. 111:102078.

Kleinschroth, F., and Kowarik, I. (2020). COVID-19 crisis demonstrates the urgent need for urban greenspaces. Front. Ecol. Environ. 18, 318. doi: 10.1002/fee.2230

Kremen, C., and Merenlender, A. M. (2018). Landscapes that work for biodiversity and people. Science 362, eaau6020. doi: 10.1126/science.aau6020

Laborde, D., Martin, W., Swinnen, J., and Vos, R. (2020). COVID-19 risks to global food security. Science 369, 500-502. doi: 10.1126/science.abc4765

Lai, K. Y., Webster, C., Kumari, S., and Sarkar, C. (2020). The nature of cities and the Covid-19 pandemic. Curr. Opin. Environ. Sustain. 46, 27-31.

Landor-Yamagata, J. L., Kowarik, I., and Fischer, L. K. (2018). Urban foraging in Berlin: people, plants and practices within the metropolitan green infrastructure. Sustainability 10, 1873. doi: 10.3390/su10061873

Laurien, F., Hochrainer-Stigler, S., Keating, A., Campbell, K., Mechler, R., and Czajkowski, J. (2020). A typology of community flood resilience. Reg. Environ. Change. 20, 1-14.

Leclère, D., Obersteiner, M., Barrett, M., Butchart, S. H., Chaudhary, A., De Palma, A., et al. (2020). Bending the curve of terrestrial biodiversity needs an integrated strategy. Nature 585, 551-556. doi: 10.1038/s41586-020-2705-y

Mabhaudhi, T., Chimonyo, V. G., and Modi, A. T. (2017). Status of underutilised crops in South Africa: opportunities for developing research capacity. Sustainability 9, 1569. doi: 10.3390/su9091569

Majumdar, P., Biswas, A., and Sahu, S. (2020). COVID-19 pandemic and lockdown: cause of sleep disruption, depression, somatic pain, and increased screen exposure of office workers and students of India. Chronobiol. Int. 37, 1191-1200. doi: 10.1080/07420528.2020.1786107

Manditsera, F. A., Luning, P. A., Fogliano, V., and Lakemond, C. M. (2019). Effect of domestic cooking methods on protein digestibility and mineral bioaccessibility of wild harvested adult edible insects. Food Res. Int. 121, 404-411. doi: 10.1016/j.foodres.2019.03.052

Maroyi, A. (2014). Traditional and medicinal uses of essential oil producing tree Sclerocarya birrea in south-central Zimbabwe. J. Essent. Oil-Bear. Plants. 17, 776-786.

McLain, R. J., Poe, M. R., Urgenson, L. S., Blahna, D. J., and Buttolph, L. P. (2017). Urban non-timber forest products stewardship practices among foragers in Seattle, Washington (USA). Urb. Forest. Urb. Green. 28, 36-42. doi: 10.1016/j.ufug.2017.10.005

Mollee, E., Pouliot, M., and McDonald, M. A. (2017). Into the urban wild: collection of wild urban plants for food and medicine in Kampala, Uganda Land Use Policy 63, 67-77. doi: 10.1016/j.landusepol.2017.01.020

Morrow, O., and Martin, D. G. (2019). Unbundling property in Boston's urban food commons. Urban Geogr. 40, 1485-1505. doi: 10.1080/02723638.2019.1615819

Nyman, M. (2019). Food, meaning-making and ontological uncertainty: exploring 'urban foraging'and productive landscapes in London. Geoforum 99, 170-180. doi: 10.1016/j.geoforum.2018.10.009

Parker, L. D. (2020). The COVID-19 office in transition: cost, efficiency and the social responsibility business case. Account. Audit. Account. J. 33, 1943-1967. doi: 10.1108/AAAJ-06-2020-4609

Pecl, G. T., Araújo, M. B., Bell, J. D., Blanchard, J., Bonebrake, T. C. Chen, I. C., et al. (2017). Biodiversity redistribution under climate change: impacts on ecosystems and human well-being. Science. 355, eaai9214. doi: 10.1126/science.aai9214

Petrescu, D., Petcou, C., Safri, M., and Gibson, K. (2020). Calculating the value of the commons: generating resilient urban futures. Environ. Policy Govern. 31, 159-174. doi: 10.1002/eet.1890 
Phillips, K. M., Pehrsson, P. R., Agnew, W. W., Scheett, A. J., Follett, J. R., Lukaski, H. C., et al. (2014). Nutrient composition of selected traditional United States Northern plains native American plant foods. J. Food Compos. Anal. 34, 136-152. doi: 10.1016/j.jfca.2014.02.010

Pierce, M., Hope, H., Ford, T., Hatch, S., Hotopf, M., John, A., et al. (2020). Mental health before and during the COVID-19 pandemic: a longitudinal probability sample survey of the UK population. Lancet Psychiatry 7, P883P892. doi: 10.2139/ssrn.3624264

Piñeiro, V., Arias, J., Dürr, J., Elverdin, P., Ibáñez, A. M., Kinengyere, A., et al. (2020). A scoping review on incentives for adoption of sustainable agricultural practices and their outcomes. Nat. Sustain. 3, 809-820. doi: 10.1038/s41893-020-00617-y

Pinheiro, M. D., and Luís, N. C. (2020). COVID-19 could leverage a sustainable built environment. Sustainability 12, 5863. doi: 10.3390/su12145863

Piyapromdee, S., and Spittal, P. (2020). The income and consumption effects of covid-19 and the role of public policy. Fisc. Stud. 41, 805-827. doi: 10.1111/1475-5890.12252

Poe, M. R., McLain, R. J., Emery, M. R., and Hurley, P. T. (2013). Urban forest justice and the rights to wild foods, medicines, and materials in the city. Hum. Ecol. 41, 409-422. doi: 10.1007/s10745-013-9572-1

Power, K. (2020). The COVID-19 pandemic has increased the care burden of women and families. Sustain. Sci. Pract. Policy 16, 67-73. doi: 10.1080/15487733.2020.1776561

Ray, A., Ray, R., and Sreevidya, E. A. (2020). How many wild edible plants do we eat-their diversity, use, and implications for sustainable food system: an exploratory analysis in India. Front. sustain. food syst. 4:56. doi: 10.3389 /fsufs. 2020.00056

Reyes-García, V., Fernández-Llamazares, Á., Guèze, M., and Gallois, S. (2018). Does weather forecasting relate to foraging productivity? An empirical test among three hunter-gatherer societies. Weather Clim. Soc., 10, 163-177.

Rigolon, A. (2016). A complex landscape of inequity in access to urban parks: a literature review. Landsc. Urb. Plan. 153, 160-169 doi: 10.1016/j.landurbplan.2016.05.017

Robinson, M., and Shine, T. (2018). Achieving a climate justice pathway to $1.5 \mathrm{C}$. Nat. Clim. Chang. 8, 564-569. doi: 10.1038/s41558-018-0189-7

Rockström, J., Edenhofer, O., Gaertner, J., and DeClerck, F. (2020). Planet-proofing the global food system. Nat. Food 1, 3-5. doi: 10.1038/s43016-019-0010-4

Rohr, J. R., Barrett, C. B., Civitello, D. J., Craft, M. E., Delius, B., DeLeo, G. A., et al. (2019). Emerging human infectious diseases and the links to global food production. Nat. Sustain. 2, 445-456. doi: 10.1038/s41893-019-0293-3

Rutt, R. L., and Gulsrud, N. M. (2016). Green justice in the city: a new agenda for urban green space research in Europe. Urb. Forest. Urb. Green. 19, 123-127 doi: 10.1016/j.ufug.2016.07.004

Sardeshpande, M., Rupprecht, C., and Russo, A. (2020). Edible urban commons for resilient neighbourhoods in light of the pandemic. Cities 109, 103031. doi: 10.1016/j.cities.2020.103031

Sardeshpande, M., and Shackleton, C. (2020). Urban foraging: land management policy, perspectives, and potential. PLOS ONE 15, e0230693. doi: 10.1371/journal.pone.0230693

Sarkodie, S. A., Owusu, P. A., and Leirvik, T. (2020). Global effect of urban sprawl, industrialization, trade and economic development on carbon dioxide emissions. Environ. Res. Lett. 15, 034049. doi: 10.1088/1748-9326/ab7640

Schlosberg, D. (2007). Defining Environmental Justice: Theories, Movements, and Nature. Oxford: Oxford University Press. doi: 10.1093/acprof:oso/9780199286294.001.0001

Serrat, O. (2017). “The sustainable livelihoods approach," in Knowledge Solutions, ed O. Serrat (Springer, Singapore), 21-26.

Shackleton, C. M., Blair, A., De Lacy, P., Kaoma, H., Mugwagwa, N., Dalu, M. T., et al. (2017a). How important is green infrastructure in small and mediumsized towns? Lessons from South Africa. Landsc. Urb. Plann. 180, 273-281. doi: 10.1016/j.landurbplan.2016.12.007

Shackleton, C. M., Hurley, P. T., Dahlberg, A. C., Emery, M. R., and Nagendra, H. (2017b). Urban foraging: a ubiquitous human practice overlooked by urban planners, policy, and research. Sustainability 9, 1884. doi: 10.3390/su9101884

Skrzypczyk, V. M., Hermon, K. M., Norambuena, F., Turchini, G. M., Keast, R., and Bellgrove, A. (2019). Is Australian seaweed worth eating? Nutritional and sensorial properties of wild-harvested Australian versus commercially available seaweeds. J. Appl. Phycol. 31, 709-724. doi: 10.1007/s10811-0181530-2

Sofo, A., and Sofo, A. (2020). Converting home spaces into food gardens at the time of covid-19 quarantine: all the benefits of plants in this difficult and unprecedented period. Hum. Ecol. 48, 131-139. doi: 10.1007/s10745-020-00147-3

Svarstad, H., and Benjaminsen, T. A. (2020). Reading radical environmental justice through a political ecology lens. Geoforum 108, 1-11. doi: 10.1016/j.geoforum.2019.11.007

Torero, M. (2020). "How to stop a looming food crisis," in Foreign Policy. Available online at: https://foreignpolicy.com/2020/04/14/how-to-stop-foodcrisis-coronavirus-economy-trade/ (accessed April 23, 2020).

Ugolini, F., Massetti, L., Calaza-Martínez, P., Cariñanos, P., Dobbs, C., Ostoić, S. K., et al. (2020). Effects of the COVID-19 pandemic on the use and perceptions of urban green space: an international exploratory study. Urb. Forest. Urb. Green. 56, 126888. doi: 10.1016/j.ufug.2020.126888

Ullah, H., Nagelkerken, I., Goldenberg, S. U., and Fordham, D. A. (2018). Climate change could drive marine food web collapse through altered trophic flows and cyanobacterial proliferation. PLoS Biol. 16, e2003446. doi: 10.1371/journal.pbio.2003446

Venter, Z., Barton, D., Gundersen, V., Figari, H., and Nowell, M. (2020). Urban nature in a time of crisis: recreational use of green space increases during the COVID-19 outbreak in Oslo, Norway. Environ. Res. Lett. 15, 1748-9326. doi: $10.1088 / 1748-9326 / a b b 396$

Walker, P. A., and Hurley, P. T. (2004). Collaboration derailed: the politics of "community-based" resource management in Nevada County. Soc. Nat. Resour. 17, 735-751. doi: 10.1080/08941920490480723

Walmsley, T. L., Rose, A., and Wei, D. (2020). Impacts on the US macroeconomy of mandatory business closures in response to the COVID-19 pandemic. Appl. Econ. Lett. 28, 1293-1300. doi: 10.1080/13504851.2020.1809626

Wang, Q., and Su, M. (2020). A preliminary assessment of the impact of COVID19 on environment-a case study of China. Sci. Total Environ. 728, 138915 doi: 10.1016/j.scitotenv.2020.138915

Weyer, D., Shackleton, C. M., and Adam, Y. O. (2018). HIV/AIDS and other household shocks as catalysts of local commercialization of nontimber forest products in Southern Africa. Dev. Policy Rev. 36, 285-301. doi: 10.1111/dpr.12261

Wild Foodies of Philadelphia. (2016). The Wild Foodies of Philadelphia: In Search of Food Beneath our Feet! Available online at: wildfoodies.org (accessed March 12, 2021).

Wolch, J. R., Byrne, J., and Newell, J. P. (2014). Urban green space, public health, and environmental justice: the challenge of making cities 'just green enough'. Landsc. Urban Plan. 125, 234-244. doi: 10.1016/j.landurbplan.2014.01.017

Zietsman, M. Y., Montaldo, N. H., and Devoto, M. (2019). Plant-frugivore interactions in an urban nature reserve and its nearby gardens. J. Urb. Ecol. 5, juz021. doi: 10.1093/jue/juz021

Conflict of Interest: The authors declare that the research was conducted in the absence of any commercial or financial relationships that could be construed as a potential conflict of interest.

Publisher's Note: All claims expressed in this article are solely those of the authors and do not necessarily represent those of their affiliated organizations, or those of the publisher, the editors and the reviewers. Any product that may be evaluated in this article, or claim that may be made by its manufacturer, is not guaranteed or endorsed by the publisher.

Copyright (c) 2021 Sardeshpande, Hurley, Mollee, Garekae, Dahlberg, Emery and Shackleton. This is an open-access article distributed under the terms of the Creative Commons Attribution License (CC BY). The use, distribution or reproduction in other forums is permitted, provided the original author(s) and the copyright owner(s) are credited and that the original publication in this journal is cited, in accordance with accepted academic practice. No use, distribution or reproduction is permitted which does not comply with these terms. 